\title{
Nutritional assessment of lactating women in Shiraz in relation to recommended dietary allowances
}

\section{S.M.T. Ayatollahi'}

$$
\begin{aligned}
& \text { التقييم التغذوي للأمهات المرضعات في شيراز وعلاقته بالمخصصات الغذائية الموحى بها }
\end{aligned}
$$

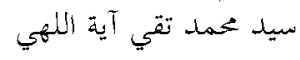

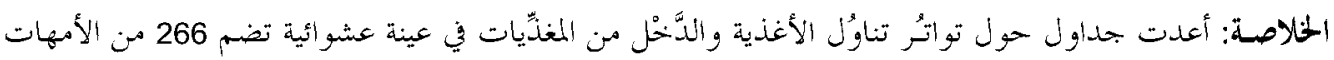

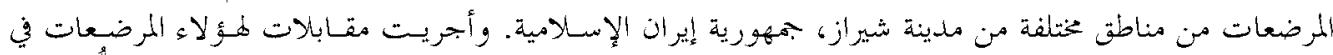

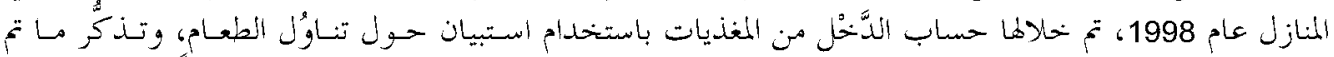

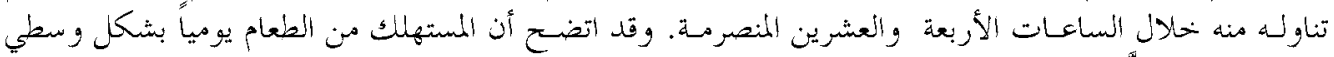

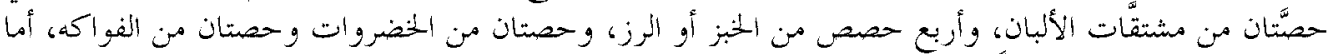

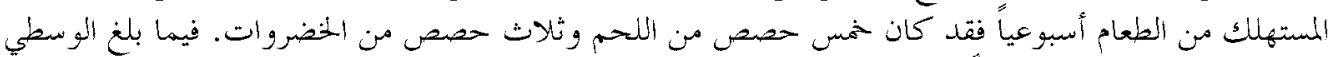

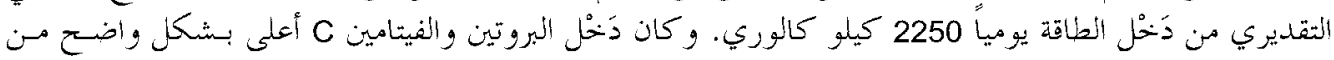

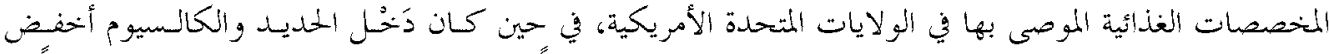

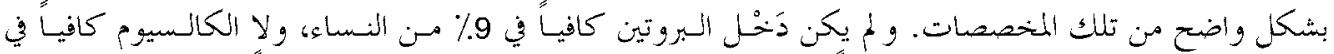

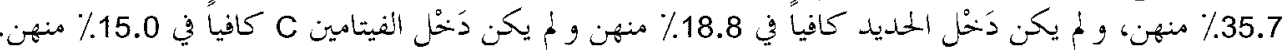

ABSTRACT Tables of food frequency and nutrient intake were created for a random sample of 266 lactating women from different areas of Shiraz city, Islamic Republic of Iran. Women were interviewed at home in 1998 and nutrient intake was calculated from a food frequency questionnaire and 24-hour dietary recall. On average, daily consumption was 2 servings of dairy foods, 4 of bread/rice, 2 of vegetables and 3 of fruits; weekly consumption was 5 servings of meat and 3 of legumes. Estimated average daily energy intake was $2250 \mathrm{kcal}$. Protein and vitamin C intake were significantly higher than United States recommended dietary allowances (RDA), while iron and calcium intake were significantly lower. Protein intake was insufficient among $9.0 \%$ of women, calcium in $35.7 \%$, iron in $18.8 \%$ and vitamin C in $15.0 \%$.

\begin{abstract}
L'évaluation nutritionnelle des femmes allaitantes à Chiraz par rapport aux apports alimentaires recommandés

RÉSUMÉ Des tableaux concernant la fréquence de consommation alimentaire et les apports en nutriments ont été établis pour un échantillon aléatoire de 266 femmes allaitantes issues de différents quartiers de la ville de Chiraz (République islamique d'Iran). Ces femmes ont été interrogées à domicile en 1998 et l'apport en nutriments a été calculé à partir d'un questionnaire de fréquence de consommation et du rappel des 24 heures. En moyenne, la consommation quotidienne comprenait deux portions de produits laitiers, quatre portions de pain/riz, deux portions de légumes et trois de fruits ; la consommation hebdomadaire était de cinq portions de viande et de trois portions de légumes. L'apport énergétique quotidien moyen estimé s'élevait à $2250 \mathrm{kcal}$. L'apport en vitamine $C$ et en protéines était significativement plus élevé que les apports alimentaires recommandés aux États-Unis d'Amérique tandis que l'apport en calcium et en fer était significativement inférieur. L'apport était insuffisant chez $9,0 \%$ des femmes pour les protéines, chez 35,7 \% des femmes pour le calcium, chez $18,8 \%$ des femmes pour le fer et chez $15,0 \%$ des femmes pour la vitamine $\mathrm{C}$.
\end{abstract}

${ }^{1}$ Department of Biostatistics and Epidemiology, School of Public Health, Shiraz University of Medical Sciences, Shiraz, Islamic Republic of Iran.

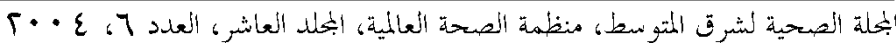




\section{Introduction}

Current guidelines published by national advisory bodies for nutrient intakes during lactation differ around the world, even between neighbouring countries with essentially similar populations [1], reflecting the inadequacy of knowledge about nutrient requirements in human reproduction. Lactation places nutritional demands on the mother for milk production [2-4]. An examination of studies on nutritional assessment indicates the importance of recording food habits and nutrient intakes in pregnant and lactating women and their effects on mothers and children. Nutritional status relates to and varies with socioeconomic, cultural and demographic factors [5-10]. However, nutrient intakes are generally compared with the United States (US) National Academy of Sciences recommended dietary allowance (RDA) [11].

Knowledge about the nutritional status of lactating women in the Islamic Republic of Iran is minimal and inadequate. Only one clinic-based study [12] has been carried out in 1978 on a group of 88 urban pregnant women of different socioeconomic status in Tehran, the capital of the country, comparing their nutrient intakes with US RDAs. The energy intake of women of middle socioeconomic status was within the safety margin of RDA (2200 kcal) but for women of low socioeconomic status $(1880 \mathrm{kcal})$ it was significantly lower than RDA. Vitamin C intake was adequate in both groups but calcium intake was below RDA in both groups, especially the disadvantaged women.

At present, there is no data on dietary intakes available for lactating mothers in the Islamic Republic of Iran. Therefore, this study aimed to provide a baseline food frequency table and assess the intakes of essential nutrients of a representative ran- dom sample of healthy lactating mothers in Shiraz, one of the five principal cities in the country and the most developed city in the south.

\section{Methods}

A $2 \%$ random sample of 266 lactating mothers was selected in 1998. Subjects were selected from different geographical areas of Shiraz city, using a probability proportional to size sampling method.

The women were visited at home and given a face-to-face interview by a trained member of the research team. A structured food frequency questionnaire and a 24hour dietary recall questionnaire were used to record the types, amounts and frequencies of foods consumed.

The food frequency intake for different types of food was defined by the author as:

$$
\sum_{i=1}^{k} k_{i} n_{i} / \sum_{i=1}^{k} n_{i}
$$

where $k_{i}$ was the midpoint of number of servings in category $k$, and $n$ the number of lactating women who had $k_{i}$ servings of food daily or weekly, whichever applied.

This index presents the average food consumption of mothers for whom calorie intake was calculated properly. Applying this procedure, food frequency tables were drawn up for various kinds of foods on a daily or weekly basis, as appropriate.

The weights of foods consumed were calculated from the recall data. In the case of complex dishes, quantities of ingredients were calculated from standard recipes. From this data, the daily intake of 4 essential nutrients (protein, iron, calcium and vi$\operatorname{tamin} C$ ) was estimated. These values were compared with the US RDAs [3] using $S A S$ software, version 8.02, and $t$-tests and sign tests where appropriate.

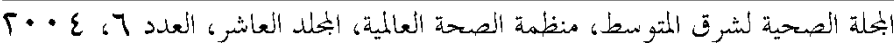




\section{Results}

Table 1 presents the food frequency intake of food items on a daily basis. Lactating women consumed on average 1.9 servings of dairy products, 3.2 servings of bread or rice, 1.8 servings of vegetables and 1.7 servings of fruits daily. Food frequency intake for foods consumed weekly are shown in Table 2. The women on average had 4.9 servings of meat, 3.0 servings of eggs and 2.8 servings of legumes or cereals on a weekly basis.

Table 3 presents the daily nutrient intake of the lactating mothers and the relevant summary statistics. Daily mean (SD) intakes were estimated as 78 (14) g protein, 13 (4) mg iron, 1054 (282) mg calcium and 156 (57) $\mathrm{mg}$ vitamin C respectively. Protein and vitamin $C$ intakes were on average significantly higher than the RDA $(120 \%$ and $164 \%$ of RDA respectively). However, iron and calcium consumption were significantly lower than the RDA $(87 \%$ and $88 \%$ of RDA respectively).

The distribution of daily nutrient intake of lactating mothers by categories of sufficiency in relation the RDA is shown in Table 4 . Nutrient intakes were insufficient

\begin{tabular}{|c|c|c|c|c|c|c|c|}
\hline \multirow[t]{3}{*}{ Food (serving) } & \multirow{2}{*}{\multicolumn{2}{|c|}{$<1$}} & \multirow{2}{*}{\multicolumn{2}{|c|}{$\begin{array}{c}\text { Daily servings } \\
1-2\end{array}$}} & \multirow{2}{*}{\multicolumn{2}{|c|}{$3-4$}} & \multirow{3}{*}{$\begin{array}{c}\text { Average } \\
\text { no. of } \\
\text { servings/ } \\
\text { woman }\end{array}$} \\
\hline & & & & & & & \\
\hline & $\begin{array}{l}\text { No. of } \\
\text { women }\end{array}$ & $\%$ & $\begin{array}{c}\text { No. of } \\
\text { women }\end{array}$ & $\%$ & $\begin{array}{l}\text { No. of } \\
\text { women }\end{array}$ & $\%$ & \\
\hline Milk (240 mL) & 148 & 55.6 & 117 & 44.0 & 1 & 0.4 & 0.9 \\
\hline Yoghurt(100 g) & 121 & 45.5 & 145 & 54.5 & 0 & 0.0 & 1.0 \\
\hline $\operatorname{Bread}(100 \mathrm{~g})$ & 1 & 0.4 & 229 & 86.1 & 36 & 13.5 & 1.8 \\
\hline Rice (100 g) & 27 & 10.2 & 235 & 88.3 & 4 & 1.5 & 1.4 \\
\hline Vegetables $(100 \mathrm{~g})$ & 40 & 15.0 & 154 & 57.9 & 72 & 27.1 & 1.8 \\
\hline Citrus fruits $(\times 1)$ & 41 & 15.4 & 192 & 72.2 & 33 & 12.4 & 1.6 \\
\hline Non-citrus fruits $(\times 1)$ & 112 & 42.1 & 151 & 56.8 & 3 & 1.1 & 1.1 \\
\hline
\end{tabular}

Table 2 Weekly food frequency intake of 266 lactating women in Shiraz

\begin{tabular}{|c|c|c|c|c|c|c|c|c|c|}
\hline \multirow{3}{*}{ Food (serving) } & \multicolumn{8}{|c|}{ Weekly servings } & \multirow{3}{*}{$\begin{array}{c}\text { Average } \\
\text { no. of } \\
\text { servings/ } \\
\text { woman }\end{array}$} \\
\hline & \multicolumn{2}{|c|}{$<2$} & \multicolumn{2}{|c|}{$2-3$} & \multicolumn{2}{|l|}{$4-6$} & \multicolumn{2}{|c|}{$>6$} & \\
\hline & $\begin{array}{l}\text { No. of } \\
\text { women }\end{array}$ & $\%$ & $\begin{array}{l}\text { No. of } \\
\text { women }\end{array}$ & $\%$ & $\begin{array}{l}\text { No. of } \\
\text { women }\end{array}$ & $\%$ & $\begin{array}{c}\text { No. of } \\
\text { women }\end{array}$ & $\%$ & \\
\hline Meat $(90 \mathrm{~g})$ & 8 & 3.0 & 73 & 27.4 & 107 & 40.2 & 78 & 29.3 & 4.9 \\
\hline Legumes (120 g cooked) & 57 & 21.4 & 186 & 69.9 & 18 & 6.8 & 5 & 1.9 & 2.8 \\
\hline Eggs (× 1) & 43 & 16.2 & 161 & 60.5 & 49 & 18.4 & 13 & 4.9 & 3.0 \\
\hline Cheese (30 g) & 49 & 18.4 & 135 & 50.8 & 61 & 22.9 & 21 & 7.9 & 3.1 \\
\hline
\end{tabular}




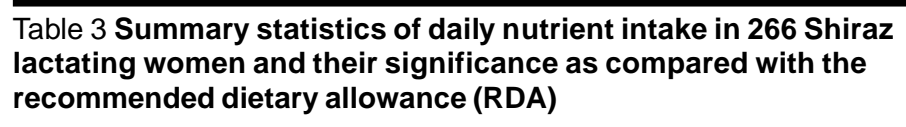

\begin{tabular}{|c|c|c|c|c|c|}
\hline \multirow[t]{2}{*}{ Nutrient } & \multirow[t]{2}{*}{$R D A^{a}$} & \multicolumn{3}{|c|}{ Daily intake of nutrient } & \multirow[t]{2}{*}{ P-value } \\
\hline & & Mean (SD) & $95 \% \mathrm{Cl}$ & $\% R D A$ & \\
\hline Protein $(\mathrm{g})$ & 65 & $78(14)$ & $77-80$ & 120 & $<0.001$ \\
\hline Iron (mg) & 15 & $13(4)$ & $12-13$ & 87 & $<0.001$ \\
\hline Calcium (mg) & 1200 & $1054(282)$ & $1020-1088$ & 88 & $<0.001$ \\
\hline Vitamin C (mg) & 95 & $156(57)$ & $149-163$ & 164 & $<0.001$ \\
\hline
\end{tabular}

among $9.0 \%$ of lactating mothers for protein, $35.7 \%$ for calcium, $18.8 \%$ for iron and $15.0 \%$ for vitamin $\mathrm{C}$, compared with the RDA reference data.

The mean calorie intake of this group of lactating mothers was estimated to be 2250 kcal per day (range 1500 to $2900 \mathrm{kcal}$ ).

\section{Discussion}

Food frequency tables for lactating women of Shiraz are presented in this paper for the first time to form a baseline for further studies. The women consumed on average 2 servings of dairy products, 3 servings of bread or rice, 2 servings of vegetables and 3 servings of fruits daily. The subjects had 5 servings of meat and 3 servings of legumes or cereals weekly. The calorie intake of lactating mothers was estimated to be $2250 \mathrm{kcal}$ per day, which is lower than the RDA ( $2700 \mathrm{kcal}$, i.e. $83 \%$ of RDA) but in the range of some other studies $[5,10]$.

This study assessed 4 of the most important nutrients for lactating mothers that play a role in milk production (protein, iron, calcium and vitamin C) [14-16]. A comparison of our results with a study in 1978 shows that, compared with the middleclass women of Tehran, lactating mothers in Shiraz consumed more calcium and vita- min C, less iron and similar amounts of protein and calories (ratio of 0.95 protein, 1.34 calcium, 1.95 vitamin $C, 0.71$ iron and 0.90 calories) [12]. Changing food habits and lifestyle over the 25-year period could be a reason, especially for the high vitamin $\mathrm{C}$ consumption among the lactating moth-

Table 4 Distribution of daily nutrient intake in relation to recommended dietary allowance (RDA) in 266 lactating women in Shiraz

\begin{tabular}{lcrr}
\hline Nutrient & $\begin{array}{c}\text { RDA } \\
\text { category }\end{array}$ & $\begin{array}{c}\text { No. of } \\
\text { women }\end{array}$ & $\%$ \\
\hline Protein $(g)$ & & & \\
$<60$ & Insufficient & 24 & 9.0 \\
$60-64$ & Satisfactory & 20 & 7.5 \\
$65+$ & Sufficient & 222 & 83.5 \\
Calcium $(m g)$ & & & \\
$<1000$ & Insufficient & 95 & 35.7 \\
$1000-1199$ & Satisfactory & 76 & 28.6 \\
$1200+$ & Sufficient & 95 & 35.7 \\
Iron $(m g)$ & & & \\
$<10$ & Insufficient & 50 & 18.8 \\
$10-14$ & Satisfactory & 149 & 56.0 \\
$15+$ & Sufficient & 67 & 25.2 \\
Vitamin C $(m g)$ & & & \\
$<90$ & Insufficient & 40 & 15.0 \\
$90-119$ & Satisfactory & 24 & 9.0 \\
$120+$ & Sufficient & 202 & 75.9 \\
\hline
\end{tabular}

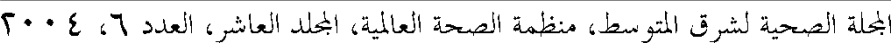


ers of Shiraz who are in the habit of eating their food with citrus fruit juices and vinegar.

At $1054 \mathrm{mg} /$ day, the mean calcium intake of our lactating women is within the safety margin of values from Northern Europe and North America. Intakes of 200$500 \mathrm{mg}$ calcium/day are typical in African and Asian societies where the consumption of animal milks is low [17], while the average consumption of calcium in Northern Europe, North America and Australia is in excess of $1000 \mathrm{mg} /$ day [18]. The protein intake of our subjects was within the range of other studies [5-9].

The US RDAs are designed to meet the needs of the majority of the population and include a safety margin of $30 \%$ of average requirements [10]. Direct analysis of dietary components indicated that on average lactating mothers were consuming more than sufficient amounts of protein, with a mean of $120 \%$ of the RDA. The iron and calcium intakes of this study, although only $87 \%$ and $88 \%$ of the RDA respectively, were also within this safety margin. However, mothers were consuming vitamin $\mathrm{C}$ beyond the safety margin of $30 \%$ with a mean of $164 \%$ of RDA. This is because women in Shiraz traditionally consume cit- rus fruits with their dishes, as the city is located in a region of citrus fruit production.

The food frequency questionnaire method designed for this study has proved to be flexible and feasible in that it can be used for short-term or long-term dietary recall, and for estimating partial or complete diets, and was administered by an expert interviewer, taking cultural as well as traditional and environmental aspects of nutrition into account. However, to make a more comprehensive study, we suggest using samples from different provinces of the Islamic Republic of Iran in a populationbased study using food record methods, which are a more accurate method of assessing dietary intake [19-21]. The tables provided here may serve as a baseline until further studies are carried out.

\section{Acknowledgements}

This work was partially supported by a grant from the Iranian Ministry of Health and Medical Education. The author is grateful to Dr Zohre Mazloom for her valuable comments, and $\mathrm{Mr}$ A.R. AnsariMoghaddam for his expert interviewing in the data gathering phase of the study.

\section{References}

1. Truswell AS et al. Recommended dietary allowances around the world. A Report by Committee $1 / 5$ of the International Union of Nutritional Sciences (Part 1). Nutrition abstracts and reviews, 1983, 53:939-1119.

2. Specker BL. Nutritional concerns of lactating women consuming vegetarian diets. American journal of clinical nutrition, 1994, 59(suppl.):1182S-6S.

3. Harfouche JK. The state of child health in the Eastern Mediterranean Region. Alexandria, World Health Organization
Regional Office for the Eastern Mediterranean, 1995.

4. Williams SR. Basic nutrition and diet therapy, 10th ed. St Louis, Missouri, Mosby, 1995.

5. Reynolds RD et al. Nutritional and medical status of lactating women and their infants in Kathmandu valley of Nepal. American journal of clinical nutrition, 1988, 47(4):722-8.

6. Moser PB et al. Copper, iron, zinc and selenium dietary intake and status of

البحلة الصحية لشرق المتو سط، منظمة الصحة العالمية، البخلد الصاشر، العدد لج، ع • +. 
Nepalese lactating women and their breast-fed infants. American journal of clinical nutrition, 1988, 47(4):729-34.

7. Butte NF, Calloway DH, Van Duzen JL. Nutritional assessment of pregnant and lactating Navajo women. American journal of clinical nutrition, 1981, 34(10): 2216-28.

8. Lewis JS, Glaspy MFE. Food habits and nutrient intakes of Filipino women in Los Angeles. Journal of the American Dietetic Association, 1975, 67:122-5.

9. Musaiger AO. Food habits of mothers and children in two regions of Oman. Nutritional and health, 1996, 11(1):2948.

10. Landman JP, Hall JE. Dietary patterns and nutrition in pregnancy in Jamaica. Journal of tropical pediatrics, 1989, 35: 185-9.

11. National Research Council, Food and Nutrition Board. Recommended dietary allowances, 9th ed. Washington, DC, National Academy of Sciences, 1980. (http://www.nal.usda.gov/fnic/dga/ rda.pdf, accessed 20 March 2005).

12. Geissler C, Calloway DH, Margen S. Lactation and pregnancy in Iran. II. Diet and nutritional status. American journal of clinical nutrition, 1978, 31:341-54.

13. National Academy of Sciences. Recommended dietary allowances, 10th ed. Washington DC, National Academy Press, 1997.
14. McWilliams C. Nutrition for the growing years, 4th ed. Boston, Jones and Bartlett, 1995.

15. Zeman FJ, Ney DM. Applications in medical nutrition therapy, 2nd ed. New Jersey, Simon and Schuster, 1996.

16. Stanfield P. Nutrition and diet therapy, 3rd ed. Boston, Jones and Bartlett, 1996.

17. Prentice A. Functional significance of marginal calcium deficiency. In: Pietrzik $\mathrm{K}$, ed. Modern lifestyles, lower energy intake and micronutrient status. London, Springer-Verlag, 1991:139-54.

18. Prentice A. Maternal calcium requirements during pregnancy and lactation. American journal of clinical nutrition, 1994, 59(suppl.):477S-82S.

19. Wilkens LR, Lee J. Nutritional epidemiology. In: Gail MH, Benichou J, eds. Encyclopaedia of epidemiologic methods. Chichester, John Wiley, 2000: 65068.

20. Margetts BM, Nelson M, eds. Design concepts in nutritional epidemiology. Oxford, Oxford University Press, 1997.

21. Nelson $M$ et al. Between and withinsubject variation in nutrient intake from infancy to old age: estimating the number of days required to rank dietary intakes with desired precision. American journal of clinical nutrition, 1989, 50: 155-67.

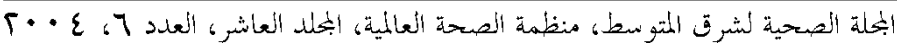

